\title{
How Language Change Actually Took Place
}

'Altering' in Late Ottoman Legal and Bureaucratic Practice

\section{Marc Aymes}

\section{(2) OpenEdition \\ Journals}

\section{Electronic version}

URL: https://journals.openedition.org/ejts/6914

DOI: 10.4000/ejts.6914

ISSN: $1773-0546$

Publisher

EJTS

\section{Electronic reference}

Marc Aymes, "How Language Change Actually Took Place ", European Journal of Turkish Studies

[Online], 31 | 2020, Online since 04 May 2021, connection on 01 June 2021. URL: http://

journals.openedition.org/ejts/6914 ; DOI: https://doi.org/10.4000/ejts.6914

This text was automatically generated on 1 June 2021 .

(C) Some rights reserved / Creative Commons license 


\section{How Language Change Actually Took Place}

'Altering' in Late Ottoman Legal and Bureaucratic Practice

Marc Aymes

This piece is an offshoot of a book manuscript in progress, originally translated from the French by Adrian Morfee, to whom I owe a peculiar debt of gratitude. All language mistakes shall be my own.

\section{But First, a Reading-and Some Reflections on How to Deal with Precarious Documents}

Reading \#1: Carbon copy of a note from the Ministry of Finance, Directorate of Public Debt and Monetary Operations, to the Accountancy Department at the Directorate of General Security, 14 Rebî̀ü'l-âHır 1340 [December 15, 1921]

1 The document starts with a short list:

1 - Documents whose forged nature is evident to the naked eye.

2 - Documents of dubious appearance.

3 - Monetary documents unfit for circulation, that is to say in which several segments are stuck together, or else combined with segments from other monetary documents.

2 Then comes the main text, with references to other correspondence, to which the following text is presented as an appendix:

The many varied monetary documents described above have been sent, with a docket, to the Public Debt Administration in order to be examined by its committee of experts, on the grounds that they are forged, dubious, or worn documents. Even when introduced by the same person, it is necessary to assign them distinct dockets, and then to have the wad of dockets signed. It has consequently been decided to present a finalized report of the case to the authorities concerned in the light of that. With the confirmation of our respect, my lord.

3 Short pre-printed note on the bottom right: 
All correspondence to be accompanied with a summary.

Please indicate the service and office to which it is addressed, including the date and number of the report being answered. legal practice. So all sorts of suspicious notes were found on a single person; ${ }^{1}$ this common origin, this collocation effect, apparently justified sending them together, under a single docket (bir bordero ile); and that is also why they are all examined by the same gaze. The introductory list of documents, one may assume, reproduces the list on said docket, in form if not in content. In so far as said documents have all been 'introduced by the same person,' the collocation may indeed seem justified on purely factual grounds. At the same time the purpose of the note is to put an end to this treatment. The argument, basically, is that neither their common origin nor the collocation justify non-distinction. The inventory presents these documents as 'forged, dubious, or worn' (sâHte veyâ şübheli veyâ fersûde), with the idea that their proximity is insufficient to define a set.

Nothing ever happens as foreseen. What the odd collocation of 'forged, dubious, or worn' documents calls into question is their readers' ability to relate each and every one of them to 'a computational space in which intentions figure prominently'-in short, an 'expert appraisal.'2 Inevitably, the problem arises of how action relates to intent, which is hard to determine. Humanistic disciplines, which by and large depend on the mediation of written artifacts, are familiar with this dilemma, which also affects social scientists getting in touch with firsthand perceptions and situations:

we do not know-and neither do the actors-what is intentionally deposited in objects, and what is produced by unintended, body-to-body material relations and creases (wearing, traces left by rubbing or knocking together, forces bringing substances into contact, unintentional phenomena and states, etc.). ${ }^{3}$

We do not know. Still, let us note that this passage grants primacy to the passive state of 'unintended, body-to-body material relations' as the main cause of wearing: it happens because things rub and knock one another, nobody is to blame. And yet, it may equally well happen because things are being worn, whenever somebody saw to it. The power of wear is thus not simply the indistinct impact of blind degradation. There is also a power of wearing, of deliberately degrading.

This power of wear has a considerable bearing on our general way of thinking about historical documents. It leads to ponder the precarious decision to read them as such, documents in their own right, or to dismiss them as 'forged, dubious, or worn' indistinctively. ${ }^{4}$ What the authors of the note drawn up by the Ottoman Ministry of Finance may have wanted to signify is that all these three types belonged to the same order of ideas, subsumed under the conundrum of alteration, be it intentional or not. Money becomes worn 'by itself,' as it were, especially when made of paper rather than clinking metal, hence forcing the authorities to make frequent standard exchanges. ${ }^{5}$ Stopping there, however, would neglect that worn money may have been worn intentionally. Part of the wear has not occurred of its own accord. In the light of this, it transpires that three dissimilar apprehensions (forgery, doubt, and wear) are in fact not as different as they may initially have appeared. Each signifies that the notes have been subjected to alterations:

- by fashioning them, which supposes that the material was deliberately worn, rendered used; this also results in any defects in conception, though detectable, becoming indistinguishable from defects caused by wear;

European Journal of Turkish Studies, 31 | 2020 
- by covering them, since the 'worn' documents are in fact (as stated in the description appended to the note) 'several segments stuck together, or else combined with segments from other monetary documents;'

- by customizing them, making them conform to convention: considering that a new-looking forgery will elicit greater distrust than one with a patina, wear will increase its credibility by rendering its appearance 'banal'-like freshly printed notes that the forger crumples and creases in his hands.

7 By imputing wear to one or several types of conditioning, and subsuming this heterogeneous group of 'forged, dubious, or worn' documents under a common heading, the administrators at the Sublime Porte are signaling that they were cognizant of the many ways a forger could hope to profit from the power of wear. A successful alteration is one that not only reproduces a canonical long-standing tradition, but also overtly displays the banal contingency of its material condition.

\section{Introduction: Language Change from Below}

8 Historical semantics always needs interlinking with other related, overlapping fields of analysis: as other contributions to this volume highlight, it cannot be conducted without combining sociolinguistical, philological, and historical methods. Broadly speaking, such an approach can be named 'historical linguistics.' What it calls for is a study not only of meanings in a language, but of their transformation over time. In the field of Middle East studies, such issues of language change have kept scholars busy for decades. Linguistic policies pursued by some countries in the region, with a view to 'simplifying' or 'purifying' language, certainly helped spark this scholarly interest (see Heyd 1954; Tachau 1964; Landau 1990, 2008; Aytürk 2004; Bayar 2011; Szurek 2013). And even in countries where 'linguistic engineering' did not become a cause célèbre, it always figured high on the political agenda (Chaker 1998; Suleiman 1999, 2003). To some extent, scholarly concerns for language change actually predated the politicization of the issue, and may be traced back to the $19^{\text {th }}$ century if not earlier in history (Perry 1985).

9 An outline of scholarly studies about language change may distinguish between several distinct and combined modes of inquiry (Aitchison 2001). For the sake of ideal-typical patterning, one may polarize this multiplicity into idealist and materialist approaches respectively:

- Idealists reflect on how the development of ideas and genres translates into wordings, phrasings, and concepts. They treat language as constitutive of 'discourse.' They ponder the relationship between usage and message. (Examples include Narayana Rao, Shulman, Subrahmanyam 2001).

- Materialists reflect on how the development of technical devices impacts on the expressive capacities of languages. They study language as constitutive of artefacts-be they written or spoken, and subsumed or not under the umbrella term of 'literacy.' They ponder the relationship between medium and message. (Examples include Eisenstein 1979, 2002; Petrucci 1993; Bouza 2004; Baron, Lindquist, Shevlin 2007).

Middle East studies have by no means been left untouched by these research patterns (see Messick 1993; Sabev 2006, 2018). Some even managed to combine them over the course of their career, as illustrated by Ami Ayalon's record (1987, 2004, 2016). Those studying the more specific context of late Ottoman legal reconfigurations and 
bureaucratic reforms have undertaken similar attempts to analyse language change as a vehicle for several distinct yet connected processes-such as the enlivening of political debate through instruments of 'public opinion' (şiviloğlu 2018), or the streamlining of administrative procedures through simplification of bureaucratic officialese and standardisation of forms (Akylldı 1995). These multiple lines of inquiry, dotted and discontinuous as they may seem, connect each other in ways that highlight the need to constantly interweave the discursive development of ideas and the physical tools available to language as practice. As Reinhart Koselleck once stressed with regard to Begriffsgeschichte, '[one] must always keep in view the need for findings relevant to intellectual or material history' (Koselleck 1982: 420).

This paper therefore aims to help "make appear the different distinctive and articulated levels of analysis that a tentative history of modern political languages calls for. ${ }^{6}$ In particular, in addressing issues of form and formalization, it rests on the assumption that words tend to adapt to phrases rather than the contrary. The argument put forward by philologists Pierre Judet de la Combe and Heinz Wismann about the (necessarily limited) formalization of 'scientific languages' here deserves careful reading:

Above and beyond words, the effort to formalize necessarily relates to the relationship between the terms thus defined. These two operations are inseparable. Scientific terms do not designate isolated entities. Rather, since they we are dealing with terminologies that seek coherence, they are signs of relationships between these entities. ${ }^{7}$

This means acknowledging that conceptual links strongly determine one's choice of words as well as their conveyed meanings. This applies equally well-or so I hypothesize here-to the more 'natural' language used by Ottoman men of letters. Documents from the Ottoman state's archives do not produce their formalizations using individual words, but rather by setting up phrasings, i.e. recurring syntagmatic and paradigmatic links between items that do not signify in and of themselves (see Dubreuil 2008). Hence the necessity to avoid addressing the conundrum of 'language change' single-wordedly, but rather situate it within the semantic and semiotic dialectics of multiple collocations. This amounts to consider that late $19^{\text {th }}$-century Ottoman officialese used several phrasings of 'alteration' in conjunctive or disjunctive ways.

While several other contributors to this issue have had every good reason to adopt an idealist stance, this paper, by contrast, tends to favor a materialist counterpoint. It does so by committing to a form of methodological materialism-namely, by taking language change literally, at its most material, as a physical process of alteration. This literalism by no means amounts to a case for materialist determinism. The emphasis on the materiality of phrasings primarily aims to distinguish between two kinds of historical semantics: one that rests on lexical, the other on conceptual units of analysis. Methodological materialism thus means to highlight that while conceptual repertoires draw on lexis, they also and above all implement a complex process of physically linking words into larger sets of meaning (phrases into texts, texts into documents, documents into files etc.). Alterations may emerge at each and every of these different levels, or at several such levels simultaneously. This multilayered complexity of phrasings, in particular, crucially implies that a text's concepts may not always be identical to its keywords, and that so-called 'semantic fields' are neither homogenous nor uniform. In practice, methodological materialism requires us to show the utmost 
respect for the insertion pattern of the 'conceptual network' within a text's 'basic fabric. ${ }^{8}$ I therefore beg to differ with studies that take 'the continuity of different layers of meaning' for granted (Topal 2017a: 286), hence ridding our reading of the precariousness of the textual fabric itself. It is here precisely-as the craft of diplomatics may remind us-that language change, for better or worse, takes place to begin with.

This in turn implies that one relocates the trouble with language change within a wide spectrum of documentary production. Scholars have tended to seek for sources in stabilized 'texts,' i.e. authored artifacts considered canonical or archetypal of their time, and hence credited with a self-sufficient truth value (e.g. see Paker 2006; Özmen 2016; Culang 2017; Katiboğlu 2017; Wigen 2018). Such an outsized focus on the authorial output of literati tends to downplay the conflict-ridden nature of their very authorization, a process replete with 'strategies of stabilization, differentiation, negotiation, and identity formation' (Reimitz 2014: 272). Language change, by contrast, is precisely about that: 'a society's aptitude for political imagination (involving both alterity and alteration)-what could hence be called alteronomia. ${ }^{19}$ And as a result the philologist's task is not only bent on establishing the veracity of sources; it is equally aimed at reactivating the 'alteronomic' nature of reading. It is a critical as well as technical, conflictual as well as peaceful act-hence, a political performance (Cerquiglini 1989; Duval 2007; Judet de la Combe 2008; Boureau 2018). This is why, rather than authored 'texts,' the following will let nondescript reports take centre stage. Rather than wandering the summits of grandiloquent notions, let us try and attend to the microscopic alterations of routine language (Reinkowski 2005; compare Topal 2017b).

14 This approach to language change from below, as it were, entails that one adopt a specific definition of it, one that is at odds with works on historical semantics, including those submitted for this special issue. While language change is generally understood as a wide-ranging historical process unfolding within vast diachronic limits, this article foregrounds a synchronic (or, as one reviewer suggested, 'nanodiachronic') approach to the way change could occur ad hoc in bureaucratic or legal usage. This approach furthermore implies that one scrutinize each and every piece of reading material very closely, one document or file at a time. Rather than singleworded, our protocol of analysis has to be, so to speak, single-documented. Four consecutive yet heterogeneous documents are therefore being provided in what follows. Let the reading continue.

\section{Legit Rewritings}

\section{Reading \#2: Report from the Ministry of the Interior to the Grand Vizierate, as initially drafted on 7 Kanûn-ı evvel 1316 [December 20, 1900]}

Under the terms of the memorandum received from the illustrious Commission to the town [of Istanbul] [şehir emâneti] dated 29 Teşrîn-i sânî of the year [1]316, Mahmûd Haḳkı, an inhabitant of Beşikṭ̂ş, domiciled on Serince Beg Rise in the district of Cihân-nümâ, has requested to be granted a privileged fifty-five-year concession to open a soda water manufactory. This application has been made by a petition bearing his signature. It would initially be pure soda water and subsequently water and lemonade carbonated using carbonic acid, all placed under the permanent supervision of a scientific controller designated by the Commission, 
in accordance with the state of the art. It is understood that it shall do no harm to the production of the twenty or so soda water manufactories that currently exist, and that it shall remit two thousand five hundred liras per annum to the Commission.

It being given that the production of soda water, which has been increasingly consumed for some time, comes from a large number of places of fabrication dotted around here and there, preventing their being placed under permanent supervision and inspection; it being further given that it becomes more difficult to carry out analyses of waters whose composition and manufacturing processes are open to question, the council of the Commission has drawn up a note about granting the above-mentioned concession, provided that it does not lead to any wrangling with existing producers, and that no other similar permit be subsequently granted to anyone, and without prejudice to any other clauses it shall be deemed appropriate to decree. The same report discusses the dispersal of the inspection missions to which existing places of fabrication are submitted.

This document has been sent with the above-mentioned petition, and so the memorandum of the Commission requests that the appropriate measures be taken. It and its attachments are submitted for consideration. Given the wording of the description, the conduct, instructions, and information to follow in this matter depend on the high opinion of Your vizierally protective Excellency. In this matter [the order and decree belong to His Excellency who is the fount of authority].

The drawing up of the report reveals a complex process of rewriting at work. A series of rearrangements and recompositions lead ultimately to a stabilized recommendation. Here this careful calibration is clear to see, for we are working with an amended draft, in which the initial version may be read beneath the corrections and crossings out. Hence my translation above gives a rendering of the first draft of the text, not of its finalized version. What is more, the text itself consists of several layers built up on the page, which appear in chronological order, namely:

1. a paraphrase of the petition ('arżuhâl) presented by Mahmûd Ḥaḳk1;

2. a paraphrase of the note (müzekkire) drawn up by the meeting of the Commission to the town;

3. a paraphrase of the memorandum (tezkire) sent by the latter to the Ministry of the Interior;

4. the first draft of the report from the Ministry of the Interior;

5. the second draft after amendments.

Clearly enough then, the language used in this document has been submitted to an intensive process of paraphrase, which slowly but surely, yet unevenly, altered its meaning. When the report first refers to 'manufactories' (fâbrîkalar), for instance, it is in free indirect discourse, with the word being Mahmûd Ḥakkı's, or else implicitly attributable to him. The correctors at the Ministry of the Interior then decide to use it. They could equally have been animated by the desire for terminological uniformity and opted to make the petitioner speak in their own words, rather than injecting his into their opinion. This alignment of the wording of the report on that of the initial petition is worth pointing out in its own right, irrespective of any possible reasons. It reveals the extent to which the language of Ottoman administration is permeated by processes of mixing, namely the mechanism of conserving the paraphrase and language of its subjects. The mixed nature of the reports it draws up thus also stems from this degree of porosity. Let us carry on reading. The paraphrasing process continues, yet it all of a sudden changes gear. While the Ministry of the Interior correctors had refrained from crossing 
anything out in transcribing the petition by Mahmûd Hakkı, now that they arrive at the opinion formulated by the Commission to the town, the rewriting commences. What the draft allows us to do is to compare [4] and [5]. On spotting the amendments, most seem fairly banal, a factual or procedural detail is pruned back here, a word or number omitted by the initial author is added there. Nevertheless, one of the revisions is different in kind. The first draft of the report refers indiscriminately to 'manufactories' (fâbrîkalar) and 'places of fabrication' (i'mâl-Hâneler). But in the finalized draft (see full text below, Reading \#2bis), this latter terminology has been deliberately crossed out and replaced by the former term. Is this fine tuning? In all probability. Yet the lexical operation may also denote a concern with terminology whose implications need to be properly appreciated.

Fâbrîka is, in all likelihood, the term used by the petitioner Mahmûd Hakḳı. As illustrated above, it was usual for the paraphrases of the Ottoman chancelleries to inset the words-and sentences even-of the petitions presented for their examination. This denomination signals Mahmûd Hakḳı's intention to make his business a serious, technical, almost industrial concern (or to have it deemed to be such). Yet the men of the Commission to the town were apparently careful in their subsequent deliberations not to adopt the term, preferring the more generic i'mâl-Hâne. Referring to 'sites of fabrication' does not imply any particular technical or social organization of labor. It is more or less the same as talking about workshops. Is this a way for those writing the Commission's report to indicate skepticism about the technical claims made by Mahmûd Hakḳı; or on the contrary are they carefully distinguishing this project from existing means of production? Whatever their intentions, the clerks reading the draft at the Ministry of the Interior have overturned them, deciding to retain the appellation fâbrik $a$ for the entire text. Once again there is no way of knowing if this choice was technically motivated. It was more probably to avoid a legal risk subsequently influencing the holding of inspections, should there have been any grounds for an ambivalent distinction between places of production, with some being presumed less industrial than others. As a matter of fact the replacement of the lexical item fâbrîka with imâl-Hâne entails a visible harmonization of the terminology applied to the production of soda waters. It is a way of emphasizing that such an activity implies standardized machinery, hence equal obligations of technical reliability incumbent on all. Ultimately the point is that the science of soda waters, however doubtful its underpinnings, may not be assimilated to a straightforward craft. Lexical fine tuning is actually transforming the material of the text, and also acting on its overall locutionary framework. In short, it is not a matter of substituting one word for another, term for term, but of another voice making different utterances.

Let us now read again the finalized draft as written up. What its reveals, albeit in a few sentences (highlighted in bold below), is that composition also entails extraction:

\section{Reading \#2bis: Report from the Ministry of the Interior to the Grand Vizierate, as finalized and written up on 5 Ramażân 1318 / 14 Kanûn-ı evvel 1316 [December 27, 1900]}

Under the terms of the memorandum received from the illustrious Commission to the town [of Istanbul] [şehir emâneti] dated 29 Teşrîn-i sânî of the year [1]316, numbered five hundred nine, Maḥmûd Haḳk has requested to be granted a privileged fifty-five-year concession to open a soda water manufactory. This application has been made by a petition bearing his signature. It would initially be producing pure soda water and subsequently water and lemonade carbonated 
using carbonic acid, all placed under the permanent supervision of a scientific controller designated by the Commission, in accordance with the state of the art. It is understood that it shall do no harm to the production of the twenty or so soda water manufactories that currently exist, and that it shall remit two thousand five hundred liras per annum to the Commission.

It being given that the growing number of manufactories and increased consumption of soda water prevents their being placed under permanent supervision and inspection; it being further given that it is difficult to analyze waters whose composition and manufacturing processes are open to question, the Commission requests that the above-mentioned concession be granted, provided that it does not lead to any wrangling with existing producers, and that no other similar permit be subsequently granted to anyone, and without prejudice to any other clauses it shall be deemed appropriate to decree. The same report discusses the dispersal of the inspection missions to which existing manufactories are submitted.

This document and its attachments are submitted for consideration. The conduct, instructions, and information to follow in this matter depend on the high opinion of Your vizierally protective Excellency, given the wording of the description. In this matter [the order and decree belong to His Excellency who is the fount of authority].

Focusing on the parts of the text to have been modified by the correctors, one of their most readily visible characteristics is that all (but one) are cuts:

\begin{tabular}{|c|c|}
\hline First draft & Edited draft \\
\hline $\begin{array}{l}\text { Maḥmûd Ḥaḳkıı, an inhabitant of Beşikțâş, Serince Beg } \\
\text { Rise, in the district of Cihân-nümâ, has requested... }\end{array}$ & Mahmûd Ḥakkı has requested... \\
\hline It would initially be pure soda water & $\begin{array}{l}\text { It would initially be producing pure soda } \\
\text { water }\end{array}$ \\
\hline $\begin{array}{l}\text { It being given that the production of soda water, } \\
\text { which has been increasingly consumed for some time, } \\
\text { comes from a large number of places of fabrication } \\
\text { dotted around here and there, preventing... }\end{array}$ & $\begin{array}{l}\text { It being given that the growing number } \\
\text { of manufactories and increased } \\
\text { consumption of soda water prevents... }\end{array}$ \\
\hline $\begin{array}{l}\text { it becomes more difficult to carry out analyses of } \\
\text { waters }\end{array}$ & it is difficult to analyze waters \\
\hline $\begin{array}{l}\text { the council of the Commission has drawn up a note } \\
\text { about granting the above-mentioned concession }\end{array}$ & $\begin{array}{l}\text { the Commission requests that the above- } \\
\text { mentioned concession be granted }\end{array}$ \\
\hline $\begin{array}{l}\text { This document has been sent with the above- } \\
\text { mentioned petition, and so the memorandum of the } \\
\text { Commission requests that the appropriate measures } \\
\text { be taken. }\end{array}$ & $\begin{array}{l}\text { This document and its attachments are } \\
\text { submitted for consideration. }\end{array}$ \\
\hline $\begin{array}{l}\text { Given the wording of the description, the conduct, } \\
\text { instructions, and information to follow in this matter } \\
\text { depend on the high opinion of Your vizierally } \\
\text { protective Excellency. }\end{array}$ & $\begin{array}{l}\text { The conduct, instructions, and } \\
\text { information to follow in this matter } \\
\text { depend on the high opinion of Your } \\
\text { vizierally protective Excellency. }\end{array}$ \\
\hline
\end{tabular}


21 This is particularly clear regarding the geographical distribution of the producers of soda waters across Istanbul. Whereas the amended text authorizes no more than a conjecture, the first draft explicitly mentions that they are dotted around 'here and there' (ötede berüde). A similar reduction results in the extreme condensation of the observation about 'carrying out analyses' (icrâ-yı tahlîlât) which, in the text sent to the grand vizier, finally becomes the far terser 'analysis' (tahlil). Meanwhile, the circumstances of its becoming difficult (ta'assür) are eclipsed by the immobile obstacle of an irremovable difficulty ('usret).

this shows is how selective the scribes are in what they paraphrase, conserving the language of the petitioner, but reworking that of their colleagues. They authenticate the former, but significantly alter the latter, in so far as they radically recompose the purport of the account the administration presents to the grand vizier. However benign it may appear, the final crossing out signifies exactly this. It carefully excises the phrase 'given the wording of the description' (siyâk- $ı$ iş'âra nazaren), which, on first sight, looks banally ritual. For the correctors have deliberately chosen to exempt themselves from this 'given.' They have deemed it right to reformulate the 'wording.' They cannot thus truthfully claim that the grand vizier's opinion depends on it. This scruple is the final act of recomposition carried out by the paraphrase. It may thus be perceived as recognizing that rewriting all but amounts to falsification.

To no far-fetched extent, this instance of language change parallels a notion familiar to Islamic scholars, and one that frequently surfaces in late Ottoman bureaucratic or legal documents: that of tahrîf, i.e. the act of altering the language of a given text by diverting its words from their proper meaning, through a substitution of words or letters for others. ${ }^{11}$ Although paraphrase and tahrîf strongly differ in that one is considered legitimate, and the other not, both types of rewriting instantiate language change at its most material, and subsume a conundrum that in Romance languages may be referred to as philological: that of studying the alterations of meanings in language, with a view to ascertaining the veracity and authenticity of authoritative documents (Cerquiglini 1989; see Launay 2016).

At this point, paraphrase and tahrif both come as fit reminders of the interrelationships between the ideal and material dynamics of language change. They show that alterations affecting the spirit of a text rarely spare the practical integrity of its letter, and vice versa. It therefore comes as no surprise that Ottoman men of the pen make the issue of language change contingent on their philological skills to paraphrase, sum up, and condense. Change in semantics cannot be addressed regardless of change in philological practices.

\section{Undue Interpolations}

\section{Reading \#3: Report to the Commander-in-Chief of the Armies, initially drafted on 16 September 1303 [September 28, 1887], finalized on 27 Muharrem 1305 / 3 Teşrînü'l-evvel 1303 [October 15, 1887]}

Following the order and indications given by the sublime memorandum of Your commanding Excellency dated March 23 [1]303, it is said that the civil register official of the district of Ḳırk Aġaç, Süleymân Efendi, who was one of the reservists for the year ninety-six [H. 1296 / 1878-79], had the temerity, in order to avoid call- 
up, to perpetrate falsification by adding the word "step-" to the name of his father's mother as recorded in the civil register. On receiving said memorandum, requiring that an enquiry be opened and, in accordance with what it stated, legal proceedings be initiated, enquiries into the situation were made at the illustrious GovernorateGeneral of Aydin.

The report presently received in response states that round robins and a testimonial about this subject were sent by the administrative assembly of the aforesaid district, and by a special committee. According to these documents, the aforesaid was not in charge of the civil register at the time when the reservists were called up, in the years three hundred and one and two [H.1301-02 / 1883-85]. Furthermore, the term "step-" in front of the name of the father's stepmother is an old inscription, and no mark has been detected of the kind made by scratching or [erasure ${ }^{12}$ which could engender suspicion.

Appended are the copy of the round robins and testimonial in question. In this matter [the order and decree belong to His Excellency who is the fount of authority].

Following up on the idea to approach tahrîf as a type of language change running parallel to practices of bureaucratic paraphrase, we are now turning to a report showing how officials address counterfeiting practices within their administrative procedures. This move, I would suggest, is necessary if we are to shed light on how Ottoman men of the pen placed issues of language change at the core of their everyday philological practice.

What does the clerk Süleymân Efendi stand accused of by some, and exculpated by others? As we read this paraphrase of contradictory reports, the case very much appears to summarize, in only a few words, the ambiguity of what language change is about. The accusation relates to falsification by 'addition' ('ilâve); to which the defense objects that the supposed interpolation is in fact 'an old inscription' (evvelden muharrer), and that, furthermore, no 'mark of the kind made by scratching or [erasure]' has been detected (hakk ve [silinti] gibi şübheyi da'vet eder bir emâre görilemedigi). The reason for adding this last clause is enigmatic. In what does the absence of traces of erasure help dissipate suspicion of interpolation? Since the argument that it was an 'old inscription' could have been an amply sufficient defense, we face the apparent paradox of an exculpation that could be described as in some way 'hollow.' It all sounds a little paradoxical, if not contradictory.

The solution to this enigma is not to impart some sort of fuzzy logic to the authors of the report, but rather to highlight that $19^{\text {th }}$-century Ottoman officials could use several notions of 'alteration' in conjunctive or disjunctive ways, each being part of a dialectical framework of interlinked operations. Conceptually speaking, this relates to a key Begriffsgeschichte clause-namely, that 'the meaning of words can be defined exactly, but concepts can only be interpreted' (Koselleck 2011 [1972]: 20). This clause also applies to semantic analysis: any given signifier has a diffracted signified, so that a given word conveys multiple meanings. In sum, we need to determine what is referred to as 'scratching' (hakk) to begin with. Let us cloak ourselves in the garb of a lexicographer drawing up an entry in a dictionary, as did Sir James W. Redhouse when writing the entry for 'hakk' in his Ottoman-English dictionary:

hakk: 1. an engraving on anything; 2. a scraping, an abrasing; esp., an erasing writing by scraping; 3. a scratching with the finger-nails; 4. a matter's causing uneasiness. (Redhouse 1890, s.v.)

Thus hakk, in addition to scraping, also refers to engraving (giving the noun engraver: hakkâk). This duplicity is reminiscent of the 'antonymic homophones' (ażdâd) studied by 
grammarians of Arabic (Reig 1971). It makes it incumbent on us to envisage that 'ambivalence observed in the field of semantics [has] homologies and counterparts in other mental or social categories' (Ad'dâd 1960: 5). What engraving and scratching have in common is that they both involve making a certain amount of matter disappear, of hollowing out a void. However, they differ in that one of them creates forms, while the other makes them disappear. To be more precise: engraving is merely the preliminary step to the materialization of the forms it creates. It opens up a blank where the ink is to flow that will give concrete form to the work. That is why the work of engraving may ultimately be assimilated to that of scratching, which often creates a void so as to fill it at its discretion. Other such operations can be found elsewhere in Ottoman reports of falsified documents. A former regimental commander in Kırşehir, Ya'k̂ub 'seized patents for most of the landholdings, great and small, scratched out the names of their holders and inserted names as he saw fit.. ${ }^{13}$ A census secretary named Yahya Efendi tampered with an official letter sent to Beirut Command:

he scratched out the terms of address and name of a soldier. He modified the

former and the top of the envelope so that the document was addressed to Central

Command. And he replaced the name of the soldier with another one. ${ }^{14}$

When it comes to scratching or engraving, then, the hollowing out is not an end in itself, but rather a means for preparing the advent of a form-matter. Each of these quick sequences confirm that hakk operations form a chain whose 'dialectical image' needs to be pieced back together to better grasp how the falsifying language change takes place. ${ }^{15}$

This dialectical image involves semiotic links as much as it draws on semantic resources. Relationships between signs, not only troves of lexical meaning, are crucial to the analysis of what 'scratching' is about. The unit of reference is not the word, but the phrase, not the terminology but the phraseology. The semiotic viewpoint thus proceeds from the semantics of scratching. Given that scratching does not function 'in a void,' but is associated with further, supplementary operations, we now need to see how these associations transpire in language. Thus we may see that in speaking of 'scratching,' the authors of the report on Süleymân Efendi have in mind a whole set of associated ideas that are not simply defined semantically in relation to another, but also semiotically indexed to each other.

One of the most readily detectable semiotic operations in the Ottoman administrative idiom is redundancy, with its countless doublets. These are particularly useful for semiotic study as they condense associations that are so regular as to be virtually automatic. That is why they may be treated as the linguistic equivalent of a conditioned reflex. Skeptics will be tempted to view them as mere prosodic mannerism. Semanticists will find material for enriching a dictionary of synonyms. In so doing, both disqualify the conditioning as such, hindering reflection about the links between thought and utterance. It is not enough to revoke language as rhetorical artifice, or to draw up some semantic table. The semiotic question should enable us to take a step in a further direction and so better understand what linguistic conditioning can produce in terms of thinking about language change. This leads to an approach one may refer to as locutionary history (see Aymes 2013: 56).

29 Scratching, hakk, goes hand in hand with 'altering,' tagyîr. The Penal Code promulgated in 1840 by the Ottoman authorities formulates this linkage in these terms:

In virtue of the eminent stipulations of the imperial [Penal] Code, a sentence of five to ten years in a penal colony, varying depending upon the severity of the offence 
committed, shall be inflicted on individuals convicted of falsification for having imitated sublime orders issued by the very high sultanate, or official documents or others issued by agents of the sublime state, and having scratched and altered them in certain places. ${ }^{16}$

This presents material operation (hakk) back-to-back with substantive alteration (tagyîr): subtraction and substitution. The semiotics of the doublet does not engender any semantic confusion, but a form of logical equivalence. Any scratching implies alteration, and any alteration presupposes scratching. Drawing on the 'dialectical image' of the term hakk helps us see how it is able to condense the logical sequence of the phrase hakk ü tagyŷr, and thereby how the one term designates two operations, namely hollowing out and filling in. Following this logic, the paradox of the report about Süleymân Efendi is merely apparent, for whilst semantically hakk and 'ilâve are antonyms, semiotically they are one.

Semantics thus combines with semiotics to shape Ottoman conceptions of language change in bureaucratic practice. To which one may add one final, sociological rationale. For linguistic issues by no means remain, in the report about Süleymân Efendi, isolated from a reasoning about social status. As a matter of fact, much in the report revolves around the question of whether Süleymân Efendi was or not 'civil register official' (nüfûs me'mûrı). Not at all, his defenders say, at least not during the two previous years (1301-02 in the Ottoman financial calendar, corresponding to 1883-85), when the reservists were called up. But why should this refutation exculpate him in any way? After all, may it not be that the civil register was falsified by someone other than the official affected to it? Thus article 152 of the 1858 Penal Code carefully distinguishes between two different cases:

Whosoever from among officials while carrying out his office commits forgery whether by making additions between the lines of judgments or round robins or other deeds or books or registers or other records or by altering the writing or seal or signature or placing in lieu of the name of a person the name of another person, shall be sentenced to a penal colony or confinement in a fortress for minimum ten years; and if the person committing this forgery is not an official, he shall be sentenced to a penal colony or confinement in a fortress for maximum seven years. 17

These regulations codify a principle of status, which presumes greater responsibility for an official agent in carrying out his duties. They nevertheless stipulate the punishment to be applied to non-official forgers. On these grounds, establishing that Süleymân Efendi was not in charge would not exculpate him. At best, it could be hoped, were he convicted, that he would receive less severe punishment than if standing trial as an official in the course of his duties.

31 Was it nevertheless possible that Süleymân Efendi's defenders were seeking to wholly exculpate him with this argument? Did they reckon their refutation (he was not officially in charge of the civil register) could result in proceedings against him being dismissed? That would suppose a certain interpretation of the Penal Code, according to which any falsification of the register entails the liability of the official affected to keeping it. On such premises the following syllogism becomes possible:

- If the register is falsified, the official affected to keeping it shall be held liable.

- Süleymân Efendi was not the official affected to keeping it.

- Ergo he cannot be held liable for any falsification that may have occurred.

All in all, the parsimonious paraphrase makes it hard to decide how Süleymân Efendi's case was pleaded, and whether his defenders argued for a lighter sentence, or 
straightforward dismissal. To a certain extent, their above-mentioned glosses about writings and scratchings may indicate a pursuit of full and complete exculpation. More surely perhaps, the fact that a 'testimonial' (şehâdet-nâme) is appended to the file reveals the intention to clear Süleymân Efendi of any taint of suspicion by reasserting his irreproachable standing.

And there is more to this than meets the eye. For, a discreet link also exists between the argument of status and the argument of (non-)scratching-a link that draws together the three motifs described above, viz. semantic, semiotic, and sociological. To begin with, the semantic purview of hakk may be extended to yet another field: the word also means to strike off an official. Hence madrasa teacher Gâlib Efendi, guilty of having made false certificates, was sentenced to having 'his career annulled and effaced. ${ }^{18}$ This in turn shows us how another doublet, ref $\ddot{u}$ h hakk, determines a semiotic reading where literal semantics have nothing to say. Like hakk, ref can mean one thing (rising, promotion, advance) and its contrary (removal, annulling, suppression). It is only their combination in the phrase that performs their meaning. At this point, one cannot but notice how, in the argument of the defense for Süleymân Efendi, exculpation carries out the symbolic equivalent of being struck off. In removing his supposed authority, it excludes the possibility that he be found guilty of the offence of which he stands accused. De jure if not de facto, his defenders claim, Süleymân Efendi should be summarily dismissed.

As summed up in the report, then, the argument in favor of Süleymân Efendi is striking precisely for the way it combines observation of the register, seeking out any material clues, with axioms of sociological deduction. The philological critique of language change, because it so crucially combines authentication with authorization procedures, cannot rest confined to ascertaining the validity of texts. Altering one's language, in one way or another, implies a will to upset society's laws and order. Legit rewriting or undue interpolations both point to one same struggle for status and empowerment.

\section{Microscopic Emulations}

\section{Reading \#4: Investigation report (̇̇abț varaḳas1), 20 Teşrîn-i evvel 1307 [November 1, 1891]}

Mârḳo the head tailor grants and transfers to Aġob Efendi son of Tingiı the property and concession of a garden lying in the village of Ayâ Stefânos [sic]. Mister Kamâra, now deceased, a subject of the illustrious state of Russia, had previously declared he had received this garden from said Mârḳo, and obtained a deed to this effect. The above-mentioned Agob Efendi is also in possession of a deed, meaning that one of the documents in question was issued in contradiction with reality. Investigations are being conducted about persons known by name, to cast light on the counterfeit thus occurring.

Two deeds are in the hands of the heirs of the said deceased Kamâra. Although we tried to have them brought for examination, this turned out to be impossible. The Russian embassy indicated in the strongest possible terms that the legal representative of the above-mentioned heirs had deposited the acts in question at the consulate, whence consequently they could not be removed.

Nevertheless, it is of the utmost necessity and importance that the registers containing the registration formalities be also inspected and examined. When the Administration for Deeds was dissociated from the Royal Foundations, and placed under the authority of the Ministry for the Imperial Registry, these registers were 
transferred to the latter. Hence on the twentieth day of this current month, we went to the office of the Imperial Land Registry's enquiry commission. A special clerk brought the first and second volumes of the register of roofed buildings for the district of Küçük Çekmece, which include the registrations pertaining to said garden. The requisite examinations commenced.

It was observed that at the bottom of page one hundred and twenty-three of said first volume the following clause was written: "Mârko Efendi, royal head tailor and beneficiary of the concession to the garden described hereafter, consents to its being definitively transferred, for a sum of 46,500 , to Mister Kamara [sic] Petro son of Mânola. The new title deeds handed to the latter are for a garden equipped with the stationary tools known to be necessary, what people in the trade call a concession. It lies near a village, and belongs to the regularized concessions of Holy Places of Mecca and Medina. The property bears number twelve on the Istanbul road, and is bordered on one side by a public highway, on one side by the garden of the residence of the assignor Mârḳo Efendi, on one side by the land of Câkomî Cîro, and on one side by the seafront. The rent due at the end of each period is two piastres per day." The dates of 9 Zî'l-hicce of the year [12] 95 [December 4, 1878] and March 11 of the year 84 [March 23, 1868] [sic] were placed underneath.

On the other side of the page at the same level the following clause is also registered: "Mârḳo Efendi, royal head tailor and beneficiary of the concession to the property designated hereafter, consents to its being definitively transferred for a sum of 95,000, to Mister Kamara Petro son of Mânola. The new title handed to the latter is for a garden with outbuildings. It lies near a village and belongs to the foundation of Mehmed Efendi the dark-skinned acolyte, requisitioned by the Treasury of Royal Foundations. The property bears number twelve on the Istanbul road, and is bordered on either side by a public highway, on one side by the garden of the residence of the assignor Mârḳo Efendi, on one side by the land of Câkomî Cîro, and on one side by the seafront. The rent due at the end of each period is thirty piastres per month." It is dated beneath 9 Zîll-hicce of the year [12]85 [March 23, 1869] and March 11 of the year [12]84 [March 23, 1868] [resic].

Under each of these registrations there is a seal, stamped with so little ink as to be illegible. Judging from its size and shape, it must be the seal including the expression "has been collated", which is visible beneath the registrations of other transactions. But under the microscope it may be seen that these two seals have been removed from other registrations and affixed here by fingertip.

It has also been observed that only the name of the above-mentioned Kamâra is given, with this indication apparently having been deemed sufficient. Still, if we are to believe the opinion of certain members of the commission of enquiry and the observations of peers, other registrations explicitly indicate the nationality of the assignor and the assignee. Furthermore, these two deeds have been registered separately whereas, being of the same kind and dated the same day, they should have appeared one after the other.

On inspecting the second volume of the register, we expected to find recorded, under the date of 18 Rebî'ü'l-âHır of the year [12]90 and of May 2 of the year [12]89, on sheet number 82 , the two relevant deeds for the right of exploitation by the above-mentioned; but despite meticulous examination no trace was found. Apparently some of the page numbers of the register between eighty-one and ninety-nine have been scratched out, and others struck through and mixed up. Three sheets, six pages correspond to the date of the above-mentioned deeds. Despite being bound together, two of these pages have been entirely cut out, thus making the registration in the name of Agob Efendi disappear.

Given the abovementioned facts, thus interlinked, and considering that Russian subjects were only allowed to benefit from the Regulations on the transfer of property as of 27 Muharrem of the year [12]90 and March 14 of the year [1]289 [March 26, 1873], the fabricated and counterfeit nature of the recorded deed in the 
first volume in the name of the above-mentioned Kamâra has been established and proven.

The conclusions drawn from examining the documents are also confirmed by the interrogations which from the very beginning have been conducted throughout the enquiry. It being given however that nobody was able to say whose writing it was in the false registrations in question, no information has been obtained on this matter. Hence the drawing up and signing of the present explanatory statement on 20 Teşrîn-i evvel of the year [1]307 [November 1, 1891].

Recording secretary Deputy general prosecutor Interrogating officer [With their respective signatures]

Falsifiers contest social norms by emulating them. As was already the case with paraphrase, this confronts us with a seemingly paradoxical form of language change: alterations that duplicate original records, i.e. reproduce as closely as possible their narrative ordering, enunciatory style, and terminological texture. Here in this San Stefano garden case the deed of transfer institutes, via a series of descriptions, the spatial and temporal world-in a nutshell, the social circumstances-of the action related. In this sense it is a legal diegesis (see Genette 1972). The description of the 'garden granted in concession' (baģçe gedigi) displays a desire to be as precise as possible in its phrasing, at times to the point of redundancy. The legal description is explained: the garden is 'equipped with the stationary tools known to be necessary, what people of the trade call a concession' (müstaḳırr beynü'l-eșnâf gedik ta'bîr olunur âlât-ı lâzıme-i ma'lûme). And in fact the formula 'âlât-ı lâzıme' comes straight from the classical legal corpus on gedik, as does the specification about the tools being 'stationary' (müstakırr). ${ }^{19}$ The legal status of the object of the transaction is also carefully repeated. The gedik strictly speaking is one of the 'regularized concessions' whose rent was attributed to the Holy Places of Mecca and Medina (Haremeynü'lşerefeyn nizâml gedikâtı) during the reign of Mahmûd II. As for the land, it belongs to a 'requisitioned' (mazbutt) pious foundation, that is to say one placed under the oversight of the Ministry of Royal Foundations (Evkâff-ı hümâyûn nezâareti). Lastly, the land is also designated in accordance with norms: the list of all the abutting plots meets the standard for legal deeds established by sharia courts, and found in the registers where the copy was recorded. The counterfeit deed thus replicates the formality of a standard type of account, made all the easier given that this standard is unchanging. Equally, and at the same time, it appropriates the trust placed in duly registered deeds, and the certification signals they bear. Emulation involves covering as well as convention. Language change is there, but strives to remain indistinguishable from established routines.

Nevertheless, in this case the fake presents a supplementary particularity. It is in direct competition with another deed, an authentic one, which must materially disappear for the counterfeit to be successful. That implies, in parallel to the conditionings just mentioned, to extensively refashion the preexisting original. The work of the falsifiers does not just consist in the conventional covering of a deed devised from scratch. It also needs to strike at the form of the original so as to deprive it of all effectiveness. Scratching out, crossing through, or straightforward purloining of the pages concerned are all deployed to this effect. The credibility of the counterfeit requires the deed it replaces to disappear. Removing so as to better fill in-we find, once again, the 'dialectical image' associated with the procedures of scratching. The scale has changed however. It is no longer letters or words that are to be altered, but official deeds in their entirety. 

simultaneous alteration. Amongst the panoply of forms and conventions with which the falsifier protects his work, seals are a crucial accessory. These have been placed on the paper 'by fingertip' (parmak uciyla), like transfers or decals. As signs that the copy of the act has been duly certified, these seals act as a covering in both literal and figurative terms. Though to do so they have to have been 'removed from other registrations' (diger kaydlardan kaldirlarak). Was the victim of the removal in this case precisely the authentic deed torn from the register? Although the Ottoman investigators do not mention this hypothesis, it cannot be excluded. In this case we would have a fine example of what diplomatists are used to calling, in the strictest sense of the term, a forgerie:

[The deed] is a pure invention of the falsifier, even if provided with authentic validation signs (most of the time a seal) purloined from an authentic deed; at best, it only reproduces snatches of formulas taken from original deeds. (Guyotjeannin et al. 2006 [1993]: 370)

Here, however, the forger does more than reproduce snatches of formulas. The authentic deed provides a detailed description of the garden and its 'concession.' All that remains to be done is to copy it out, without altering anything other than the name of the assignee. Thus the false deed replicates the formulas of its model, whilst using its seals as transfers. Forgery backed up by plagiarism. not sufficient to strike at the certified deed. Since the original remained in the possession of its legitimate beneficiary Agob Efendi, it continues to be valid proof for contesting the misappropriation. That is where the whole case starts: since two competing acts are to hand, one has to suppose that 'one of the documents in question was issued in contradiction with reality' (senedât-ı mezkûreden biriniñ Hilâf-ı vâki' üzerine verilmiş demek olacagi). The first step of the Ottoman investigators is to have these original deeds 'brought for examination' (celb ü tedkîki). Faced with the subterfuge of depositing the forgeries at the Russian Consulate, making it impossible to confront the two, the enquiries turn to the registers held at the Land Registry. It is up to them to make the invisible reappear, even though 'no trace can be found' (hiç bir eser görilemeyüb). By tracking down the false to the limit of the indiscernible, the investigators seeking to disentangle the San Stefano garden case call on a whole battery of aids, without which nothing would be noticed. Their work as experts, like that of forgers, consists in ensuring that something is successfully made to appear. Counter conditioning with yet more conditioning: such could be the watchword of forgers and experts alike (see Grafton 1990a; Bessy, Chateauraynaud 2013).

To the naked eye, the check seals do not betray the fact that they have been manipulated. At the very most the light ink catches the experts' attention. The seals, they indicate, are 'stamped with so little ink as to be illegible' (okunmaz derecede 'ârî mürekkeble [...] bașllmış). On its own, this observation would not trigger suspicion of falsification. To tell the truth, authentic Ottoman documents are teeming with washed out and under-inked seals. It is more probably out of a desire to display their attention to detail, and discreetly vaunt their merits, that the authors of the statement linger over the legibility of these seals. What they are basically saying is that due to a lack of ink it was only possible to identify the seal by deduction based 'on its size and shape' (kıt $a$ ü şeklince). So here, the eye sees but does not discern. It is only by comparing with 
other seals of the same type that it becomes possible to recognize the indiscernible visible. Recognition proceeds by symbolization.

Yet looking for language change also involves to cope with what the eye neither sees nor discerns-emulation at its microscopic best. The microscope then becomes the key aid for the conditioning intended to reveal the false. The investigators do indeed use a microscope (Hurde-bîn), not a magnifying glass (pertev-sûz). The use of such an instrument, especially for writing, might be surprising. It nevertheless signals that the phrase 'examining the documents' (tedkîkât-ı kuyûdiyye), used by the investigators to describe their work, needs to be taken seriously. Let us return to the opening instruction that the authors of this statement issued themselves: 'it is of the utmost necessity and importance that the registers containing the registration formalities be also inspected and examined' (mu'âmelât-ı kuyûdiyyeyi ḥâvî olan [...] defâtiriñ daĤ̀̂ $m u$ âyene ü tedkîki ehemm ü elzem). Lexical derivation indicates that inspection (mu'âyene) is still a matter of ocular observation ('ayn). But examination as described by tedkik is one that renders its object unrecognizable:

tedkîk: 1. a bruising, pounding, or grinding finely; comminution; 2. a making slender or fine; 3. a minutely examining, investigating; close examination, scrutiny; (s., pl. tedkîkât) investigation; 4. (philosophy) a corroborating a proof by proofs or indications; 5. (mystics) a saint's seeing by intuition and having no need of proof. (Redhouse 1890, s.v.)

The analysis thus described is of the kind that literally decomposes and thus grinds to dust. The only way of being able to distinguish the minute particles (Hurde, zerre) produced is a microscope, the use of which thus increases in significance. And what may be discerned in this case? The fact that the check seals had been transferred, 'removed from other registrations and affixed here by fingertip' (parmak uciyla diger kaydlardan kaldırılarak bașldıgi $)$. What invisible are we dealing with here, made discernible thanks to a microscopic gaze? The report does not explain. Perhaps the mention 'by fingertip' reveals part of the answer. What the washed-out ink of the seals dissimulated may have been the slender furrow of a fingerprint.

Counter conditioning with yet more conditioning. Just as the experts' examination with a microscope was even more meticulous than the forgers' feat, the investigators' skills with regard to official formulas outdoes the plagiarist's exploits. By copying literally everything that could be copied from the authentic deed, the one in favor of 'Mister Kamâra' may, for a while, seemed to have scrupulously adhered to the applicable norms. In places, however, it is not plagiarism but counterfeiting that is required, starting precisely with the identity of the assignee. And this is where the counterfeiter exposes his fallibility. He disregards the rule of 'indicating explicitly the nationality of

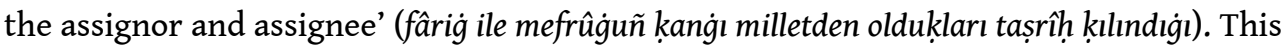
gap in the phraseology is immediately spotted by the investigators who, being experienced in such matters, are alerted to the diplomatic incongruence of the deed. This mechanism by which falsification is revealed applies just as implacably once the unusual registration procedure is noticed: 'these two deeds have been registered separately whereas, being of the same kind and dated the same day, they should have appeared one after the other' (şu iki kaydiñ târîHleri ve nev'i bir oldiǵı içün șırasıyla yazılmak îcâb eder iken ayrı ayrı kayd edildigi). A missing formula, an incongruous layout. Two slips is all it takes to suspect forgery. However, these defects only become apparent to those who have taken their time meticulously 'examining the documents,' 
and who have unrivalled knowledge of the applicable norms for legal deeds. To detect the counterfeit's mistake, one has to master the art of emulation.

Now that outer appearance has been stripped away, 'the fabricated and counterfeit nature of the recorded deed [...] has been established and ascertained' (kaydiñ müșanna ü sâHte oldiğ tebeyyün ü tahakkuk etmiş). But for the forgery to be removed from the envelope confectioned for it, the investigators have to perform two more technical steps. First, the 'abovementioned facts' (ahvâl-i mesrûde) have to appear as 'interlinked,' an additional meaning of the word mesrûd. The use of this term is far from insignificant. It is quite literally a work of stitching and binding together that the authors have performed. The expression is figurative. No doubt the time spent examining the bound pages of the register has something to do with it. Nevertheless, the image is revelatory of the method. In a way that parallels the combination of semantics with semiotics emphasized above, it signifies that analytic examination has to give way to synthetic judgment.

One final check is required, which is simply to compare dates. The late 'Mister Kamâra' was a protégé of the Russian state, and 'Russian subjects were only allowed to benefit from the Regulations on the transfer of property as of 27 Muharrem of the year [12]90 and March 14 of the year [1]289,' that is to say March 26, 1873 (Rûsya teba'asiniñ istimlâk nizâm-nâmesinden istifâdeleriniñ 27 Muharrem sene 90 ve 14 Mârt sene 289 târîHinden ittibâr edilmiş olunmasina nazaren). The deed in favor of Kamâra, for its part, is dated 9 Zî̀lhicce 1285 and March 11, 1284 (sic, no doubt for 1285), that is to say March 23, 1869. The dates do not fit. Legally, it was not possible to validate and register that early the assignation of the garden in San Stefano, a 'property' (mülk) and 'concession' (gedik), to a Russian subject such as Kamâra. The counterfeiter mixed up the legal provisions, promulgated on June 10,1867, and the enabling decree for 'Russian subjects' six years later. The investigators, being better informed of the subtleties of legislative chronology, soon spotted the misfit. ${ }^{20}$

Anachronism is a well-known and powerful technique for the criticism of fakes. It usually suffices as irrefutable proof of counterfeiting. And in this case, the administration of this proof is both elementary and decisive. So why is the charge of anachronism only mentioned at the end, as a kind of supererogation? Why precede it with a long and fastidious account which not only goes over the content of the items examined (as required), but also lists the slightest clues of their inauthenticity? One may view this as simply pernickety pride. No doubt the authors of 'this investigation report including an explanatory statement' (beyân-ı hâli müteżammın işbu żabț varakası) were careful to omit no detail of their enquiry, a way for them to display how zealous and skilled they are. But nor can we exclude the possibility that they shared a taste for carefully graduated effects, so as to hold their readers' attention through the end of their forgery report.

All exercises in reading are bound to abide by the circumscription of a certain historical setting-here, that of the Ottoman nineteenth and early twentieth centuries. Yet semantic events that occurred within the presumed limits of this 'context' may also end up exceeding them. While studying 'Ottoman semantics' within their given time and place coordinates, one is led to ponder how they could contribute to our 
understanding of historical linguistics at large. Lest their precarious documents would all end up 'forged, dubious, or worn,' Ottoman bureaucrats-cum-philologists developed a historical semantics in their own right. Reading them eventually teaches us an humbling lesson: namely, that our commitment to methodological materialism may have been theirs to begin with.

\section{Transliterations}

Source: Devlet Arşivleri Başkanlığı Osmanlı Arşivi (BOA), Istanbul.

Fac-similes of these documents may be accessed online through the following https:// doi.org/doi:10.25721/18x3-7a47.

\section{\#1: BOA, DH.EUM.MH. 224/28}

1 - SâHुteligi ‘yânen zâhir olanlar

2 - şüpheli görinenler

3 - Tedâvüle ġayr-1 șâlih ya'ni muHttelif akssâmı yekdigerine yapışdırılmış veyâ diger evrâk-ı naḳdiyye akssâmıya birleşdirilmiş evrâk-ı naḳdiyye

Main text underneath:

Sâtte veyâ şübheli veyâ fersûde olduklarından tọlâyı Düyûn-ı 'umûmiyye idâresinde müteşekkil ehl-i Hibre komisyonca tedkîk edilmek üzere bir bordero ile Düyûn-1 'umûmiyye idâresine irsâl edilmekde olan bâlâda muharrer muHtelifü'lnev' evrâk-ı naḳdiyye 'aynı şaH̆ı̣ țarafından ibrâz edilmiş olsa dânî ayrı ayrı borderoya rabṭ olunarak mezkûr borderolarıñ cüz'ine imżâ etdirilmek lâzım geldiginden keyfiyetiñ îcâb edenlere aña göre tebyîzi tensîbiyle te'yîd-i iḥtirâm olunur efendim

\section{Bottom right-hand corner (preprinted):}

Yazılacaḳ muharrerâta Hulâșa yazılması ve hangi kalem ifâdesiyle hangi müdîriyetiñ hangi târît ve nûmarûlı iş‘ârına cevâb oldıġınıñ derc olunması ricâ olunur.

\section{\#2: BOA, DH.MKT. 2443/30 (initial draft)}

El-yevm mevcûd bulunan yigirmi kadar gâazoz fâbrîkalarının i'mâlâtına Halel gelmemek ve emânete senevî iki biñ beș-yüz lîrâ i'țâ olunmaḳla berâber cânib-i emânetden ta'yîn olunacak fenn me'mûrınıñ nezâret-i mütemâdiyyesi taḥtında ve fenn dâ'iresinde şimdilik tuâliṣ ġâzoz olunmak ve ilerüde âsîd kârbonîk ile gâazozli șular ve lîmonâțalar daĤi yapılmak üzere elli beş sene müddetle bir gâazoz fâbrîkası küşâdı içün imtiyâz i'țâsı istid'âsını hâvî Beşikțâş'da Serince Beg yokuşısıda Cihânnümâ mahallesinde sâkin Mahmûd Hakḳı imżâsıyla verilen 'arżuhâlda istid'â ḳlındıġından ve bir müddetden-berü ve șarfiyâtı tekeŝŝür eden ötede berüde bir çok i'mâlât-hâneleri peydâ olan ġâzoz ma'mûlâtınıñ bi'l-żarûre taḥt-1 neẓâret ü teftîş-i dâ’imîde bulundırılamamasından ve terkîbât ü i'mâlâtında tereddüd olanlarınıñ icrâ-yı tạ̣lîlâtındaki ta'assürden bahịisle mevcûdına ilişilmemek ve ba'dezîn âHarına ruHșat verilmemek şarțı ve ta'yîn ḳlınacak şerầiț-i sâ'ire-i münâsibe ile mûmaileyh imtiyâz i'țâsı ve mevcûd i'mâl-Hูâneleriñ tâbi' oldıġı teftîşâtıñ tevşîiki [here a few characters under heavy strikethrough] hakḳıında meclis-i emânetden tanzîm olunan müżekkire mezkûr 'arżuhâl ile ma'an irsâl ḳlındıġından bahịisle icrâ-yı îcâbı istîzânı hâvî şehir emânet-i celîlesinden tevârüd eden 29 teşrîni șânî sene 316 târîtulü težkire melfûlarıyla ma'an taḳdîm ḳılınmışdır ve șûret-i iş‘âra naz̧aren îcâbınıñ icrâ ve emr ve inbâsı re'y-i sâmî-i vekâlet-penâhîlerine menûțdur bu bâbda 
\#2 bis: BOA, DH.MKT. 2443/30 (finalized draft; bold type indicates edited parts)

El-yevm mevcûd olan yigirmi ḳadar ġâzoz fâbrîkalarınıñ i‘mâlâtına Hูalel gelmemek ve emânete senevî iki biñ beş-yüz lîrâ i'țâ olunmaḳla berâber cânib-i emânetden ta'yîn olunacak fenn me'mûrını̃ neẓâret-i mütemâdiyyesi taḥtında ve fenn dâ'iresinde şimdilik Hâliṣ giâzoz i'mâl olunmak ve ilerüde âsîd kâabonîk ile gâazozli șular ve lîmonâțalar daHî yapılmak üzere elli beș sene müddetle bir gâazoz fâbrîkası küşâdı içün imtiyâz i'țâsı istid'âsını hâavî Beşikțâş'da Serince Beg yokuşısıda Cihânnümâ mahallesinde sâkin Mahmûd Hakḳı imżâsılyla verilen 'arżuhâlda istid'â ḳılındıġından ve fâbrîkaları ve șarfiyâtı tekeŝsüür eden ġâvzozuñ [sic] bi'l-żarûre taḥt-ı nez̧âret ü teftîş-i dâ'imîde bulundırılamamasından ve terkîbât ü i'mâlâtında tereddüd olanlarıñ tahlîlindeki 'usretden bahişle mevcûdına ilişilmemek ve ba‘dezîn âHarına ruHșat verilmemek şarțı ve ta'yîn ḳılınacak şerầiț-i sâ'ire-i münâsibe ile mûmaileyh imtiyâz i'țâsı ve mevcûd fâbrîkalarıñ tâbi' oldıg்ı teftîşâtıñ tevşị̂i [here a few characters under heavy strikethrough] istîzânına dâ'ir şehir emânet-i celîlesinden tevârüd eden 29 teşrîn-i şânî sene 316 târîtulü ve beş yüz tọauz nûmarûlü težkire melfûlarıyla ma'an taḳdîm ḳılınmışdır îcâbınıñ icrâ ve emr ve inbâsı re'y-i sâmî-i vekâlet-penâhîlerine menûțdur bu bâbda

\#3: BOA, DH.MKT. 1454/85

Ḳırk Ag̉ac każâsı nüfûs me'mûrı Süleymân Efendi'niñ țoksân altı senesi efrâd-1 redîfesinden oldığı hâlde silâh altına alınmaḳdan kurtulmak içün pederiniñ vâlidesiniñ nüfûs defterinde muḳayyed olan ismi üzerine bir kầ'nn lafẓı 'ilâve ile sâHtekârlığa cür'et eylediginden taḥkîkât-ı lâzıme icrâsıyla tebeyyün edecek hâle göre hakḳkında mu'âmele-i kânûniyye îfâsı vârid olan 23 mârt sene 303 târî̀nlü tezkire-i 'aliyye-i sipeh-dârîlerinde irâde ve iş‘âr buyrulmaḳdan nâş̧î keyfiyet Aydın vilâyet-i celîlesinden sû'âl edilmişidi bu kere cevâben alınan tahrîrâtda efrâd-ı redîfeniñ üçyüz bir ve iki senelerinde silâh altına alındığı zamân mûmâileyhiñ nüfûs me'mûriyetinde bulunmadıġına ve peder ve kầ'in [sic] vâlidesiniñ ismi ibtidâsındaki kầ'ın łazłł \{lafẓı\} evvelden muharrer olub hakk ve [silinti] gibi şübheyi da'vet eder bir emâre görilemedigine dầir kaażâ-1 mezkûr meclis-i idâresinden ve komîsyon-1 maHșûș̣dan verilen mażbațalarla şehâdet-nâmeniñ gönderildigi izbâr olunmuş ve zikr olunan mażbațalarla şehâdet-nâmeniñ birer șûreti leffen taḳdîm ḳlınmış olunmagîin bu bâbda ${ }^{21}$

\#4: BOA, şD. 2584/12, doc. 140

Terzi bâşı Mârḳo'nuñ Ṭınğır oğlı Ag̉ob Efendi'ye ferâg ve kaș̣r-1 yed eyledigi Ayâ Stefânos karyesinde kâ'in mülk ü gedik bir bâb baģçeyi Rûsya devlet-i faHîmesi teba'asından olub mukaddemâ vefât eden Mösyö Ḳamâra daha evvelce merkûm Mârḳo'dan teferrug ve senedini istiḥ̂âal eyledigini iddi'â ederek mûmâileyh Ag̉ob Efendi yedinde daHî sened bulundığı ve senedât-1 mezkûreden biriniñ Hilâf-1 vâkị ${ }^{\star}$ üzerine verilmiş demek olacağı cihetle bu yolda vukûu'bulan sâHูtekârlıġın zâhhire iH̆âcı żımnında ma'lûmü'l-esâmî kesân ḥaḳklarında icrâ ḳılınmaḳda olan tạ̣kîkâât șırasında müteveffa-yı merḳ̂m Ḳamâra'nuñ vereŝesi nezdinde bulunan iki kııt’a senediñ celbine teşebbüîs olunmus ise de mezkûr senedleriñ vereŝe-i merḳûmeniñ vekîli țarafından ḳonsolâtoya tevdî̀ edilmiş oldığından oradan çıkarılamayacağı Rûsya sefâretinden șûret-i kat'tiyyede iş‘âr olunmag̉la bunlarıñ celb ü tedḳ̂ki kâabil olamayub ma'-mâ-fîh mu'âmelât-1 kuyûdiyyeyi hâavî olan ve senedât idâresiniñ Evkâaf-1 hümâyûn'dan bi'l-tefrîk Defter-i Huâkânî [sic] nezâaretine ilhâḳıı eŝnâsında nezâret-i müşârünileyhâya devr edilen defâtiriñ daĤî mu âyene ü tedkị̂i ehemm ü elzem bulunmağla şehr-i hâaliñ yigirminci pâzâr güni Defter-i ţâkânî cem'iyet-i tedkîkkiyye oțasına 'azîmet ve mežkûr baģçeniñ kaydlarını hâvîi olan Çekmece-i șaġır kazzâsınıñ müsakkaafât defteriniñ cild-i evvel ve ŝânîsi me'mûr-1 maHșûș márifetiyle 
bi'l-celb tedḳ̂kâat-ı lâzımeye mübâşeret olundı mežkûr cild-i evveliñ yüz yigirmi üçünci șahîfesiniñ nihâyetinde Ḥaremeynü'l-şerefeyn niz̧âmlı gedikâtından ḳarye civârında İstânbûl câddesinde on iki nûmarû ile muraḳam bir țarafı țarîk-i âm bir țarafı fârig Mârḳo Efendi menzili bağçesi bir țarafı Câkomî Cîro 'arṣası bir țarafı lebi deryâ ile maḥdûd yevmiye iki akçe icâre-i mü'eccelelü derûnunda müstaḳırr beynü'l-eșnâf gedik ta'bîr olunur âlât-1 lâzıme-i ma'lûme ile bir bâb bag̣çe gedigine mutașarrıf olan terzi başı-1 şehriyârî Mârḳo Efendi riżâsıyla $46500{ }^{\text {bedel }}$ ile Mösyö Kamara [sic] Petro veled-i Mânola kaț '̂̀'en ferâg ederek cedîd temessük verildi 'ibâresiniñ muharrer ve 9 Ẑ̉'l-ḥicce sene 95 ve 11 Mârt sene 84 [sic] târîHleriniñ mevżû̀' edügi ve bu șahîfeniñ diger cihetinde ve 'ibâre-i mezkûreniñ hịẑasında daĤî Evḳ̂f-1 hümâyûn Hुazînesinden mażbût Ḳara Halîfe Meḥmed Efendi vaḳfından ḳarye civârında İstânbûl câddesinde on iki nûmarû ile muraḳam bir țarafı țarîk-i ‘âm bir țarafı merḳûm Mârḳo Efendi menzil bag̉çesi bir țarafı Câḳomî Cîro 'arșası bir țarafı leb-i deryâ ile maḥdûd şehriye otuz akçe icâre-i mü’eccelelü ma' müştemilât bir bâb bağçeniñ mülküne mutașarrıf olan terzi başı-1 şehriyârî Marḳo Efendi riżâsıyla 95000 bedel ile Mösyö Ḳamara Petro veled-i Mânola ḳat t'î́en ferâg ederek cedîd temessük verildi 'ibâresi muḳayyed ve bunuñ zîrinde daĤî 9 Ẑ̀'l-hicce sene 85 ve 11 Mârt sene 84 târîHiyle mü'erraH̆ bulundığı ve şu iki kaydıñ zîrlerine oḳunmaz derecede 'ârî mürekkeble iki mühür bașılmış oldığı ve bu mührüñ ḳıț'a ü şeklince diger işleriñ kaydları zîrinde müşâhede olunan "mukâbele olunmuşdur" kelimâtını hâvî mühür olmak lâzım-gelürse de Hुurde-bîn ile baḳıldıḳda bunlarıñ parmak ucıyla diger kaydlardan ḳaldırılarak bașıldığı ve cem'iyet-i tedḳîkiyye a'żâsından ba‘żılarınıñ ifâdesinden ve emŝâliniñ müțâla'asından istidlâl olundıġına nazaren ḳuyûd-1 sâ'irede fârig ile mefrûguñ ḳanġı milletden olduḳları tașrîh ḳılındığı hâlde merḳ̂um Ḳamâra'nıñ yalñı isminiñ tahrîriyle iktifâ olundığı ve şu iki ḳaydıñ târîH̆leri ve nev'i bir oldığı içün șırasıyla yazılmak îcâb eder iken ayrı ayrı ḳayd edildigi görülmüşdür cild-i ŝâ̂î defteri daĤ̂ lede'l-mu'âyene mûmâileyh Agob Efendi'niñ tașarrufunı nâțık iki kı̣ț'a senedâtıñ 18 Rebî‘ü'l-âH̆ır sene 90 ve 2 Mâyıs sene 89 târîH ve 82 varaḳa nûmarûsınıñ defter-i mezkûrda bulunması lâzım-gelen kaydı dikkatle taharrî olunmuş ise de hiç bir eŝer görilemeyüb bu defteriñ seksen birinci șahîfesinden țoḳsan țoḳuzıncı șahîfesine ḳadar olan șahîfe nûmarûlarınıñ ba‘żısı ḥakk olunmuş ve ba'żısı daĤi çizilerek ḳarıșdırılmış oldığı ve üc varaḳa altı șahîfe i'tibârıyla bir yere getirilüb teclîd edildigi hâalde mezkûr senedâtıñ târîHine müṣâdif olan șahîfeleriñ ikisi bütün bütün çıkarılaraḳ şu șûretle Ag̉ob Efendi nâmına olan ḳaydıñ maḥv edildigi müşâhede olunmuşdur ahvâl-i mesrûdeye ve Rûsya teba'asınıñ istimlâk nizâm-nâmesinden istifâdeleriniñ 27 Muharrem sene 90 ve 14 Mârt sene 289 târîtuinden i'tibâr edilmiş olunmasına naẓaren merḳ̂u Kamâra nâmına nâmına [sic] birinci cilde geçürilen kaydıñ müșanna' ü sâțte oldığ tebeyyün ü tahakḳuk etmiş ve evvel ve âHır cereyân eden taḥ̣̣̂̂ât-ı istințâkiyye daHî tedḳ̂̂kât-1 kuyûudiyyeden hâașıl olan şu netîceyi mü'eyyid ise de mezkûr sâțte ḳaydlarıñ kimiñ yazusı oldığı bilinemediginden bu cihetden ma'lûmât istiḥ̂âali ḳâbil olamamış olmag̉la beyân-ı hâli müteżammın işbu żabṭ varaḳası tanẓ̂m ü imżâa olundı fî 20 Teşrîn-i evvel sene 307

Żabṭ kâtibi Müdde'i-i 'umûmî mu'âvini Müstanțık [With their respective signatures] 


\section{BIBLIOGRAPHY}

Ad'dâd (1960). Sur les Ad'dâd : l'homonymie des contraires en arabe, Paris, École pratique des hautes études.

Aitchison, Jean (2001). Language Change: Progress or Decay?, Cambridge, Cambridge University Press (3 ${ }^{\text {rd }}$ ed.; orig. ed. Fontana Press, 1981).

Akgündüz, Ahmet (1986). Mukayeseli İslâm ve Osmanlı Hukuku Külliyatı, Diyarbakır, Dicle Üniversitesi Ukuk Fakültesi Yayınları.

Akyıldız, Ali (1995). ‘Tanzimat Döneminde Belgelerin şekil, Dil ve Muhteva Yönünden Geçirdiği Bazı Değişiklikler (1839-1856),' Osmanlı Araştırmaları XV, pp. 221-237.

Ayalon, Ami (2016). The Arabic Print Revolution: Cultural Production and Mass Readership, Cambridge, Cambridge University Press.

Ayalon, Ami (2004). Reading Palestine: Printing and Literacy 1900-1948, Austin TX, University of Texas Press.

Ayalon, Ami (1987). Language and Change in the Arab Middle East: The Evolution of Modern Political Discourse, New York London, Oxford University Press.

Aydın, Bilgin; Keskin, İshak (2008). 'Osmanlı Bürokrasisinde Evrak Sahteciliği, Diplomatik ve Diplomatika Eğitimi,' Osmanlı Araştırmaları 31, pp. 197-228.

Aymes, Marc (2019). 'La main courante de l'archivation. Deux histoires ottomanes,' in Archiver au Moyen-Orient. Fabriques documentaires (XIX ${ }^{e}$ XXI ${ }^{e}$ siècle), Jungen, Christine; Sfeir, Jihane eds., Paris, IISMM, Karthala, pp. 27-45.

Aymes, Marc (2013). 'Prêts-Noms. Politique du métonyme,' Revue d'Histoire Moderne et Contemporaine, 60(2): Bouquet, Olivier; Fliche, Benoît eds., Politiques du nom. La réforme des noms propres en Turquie, pp. 38-57. DOI: 10.3917/rhmc.602.0038

Aymes, Marc (2008). 'La fuite, le retour et la rature. Quand le style fait l'événement en Méditerranée ottomane au XIX ${ }^{\mathrm{e}}$ siècle,' Turcica 40, pp. 153-188. DOI: 10.2143/TURC.40.0.2037138

Aytürk, Illker (2004). 'Turkish Linguists against the West: The Origins of Linguistic Nationalism in Atatürk's Turkey,' Middle Eastern Studies 40(6), pp. 1-25. DOI: 10.1080/0026320042000282856

Baron, Sabrina Alcorn; Lindquist, Eric N.; Shevlin, Eleanor F. eds. (2007). Agent of Change: Print Culture Studies after Elizabeth L. Eisenstein, Amherst, MA Washington, DC, University of Massachusetts Press, Center for the Book, Library of Congress.

Bayar, Yeşim (2011). 'The Trajectory of Nation-Building through Language Policies: The Case of Turkey during the Early Republic (1920-38)," Nations and Nationalism 17(1), pp. 108-128.

Benjamin, Walter (1999). The Arcades Project (transl. by Eiland, Howard; McLaughlin, Kevin, on the basis of the German volume edited by Rolf Tiedemann), Cambridge MA, London, The Belknap Press of Harvard University Press.

Berman, Antoine (2008). L'Âge de la traduction. "La tâche du traducteur » de Walter Benjamin, un commentaire (Berman, Isabelle; Sommella, Valentina ed.), Saint-Denis, Presses universitaires de Vincennes.

Bessy, Christian; Chateauraynaud, Francis (2013). Experts et faussaires. Pour une sociologie de la perception, Paris, Éditions Pétra ( $2^{\text {nd }}$ augmented ed.; $1^{\text {st }}$ ed. 1995). 
Boureau, Alain (2018). Le Feu des manuscrits. Lecteurs et scribes des textes médiévaux, Paris, Les Belles Lettres.

Bouza, Fernando (2004). Communication, Knowledge, and Memory in Early Modern Spain (López, Sonia; Agnew, Michael transl.; orig. ed. 1999), Philadelphia, University of Pennsylvania Press.

Brunner, Rainer (2001). Die Schia und die Koranfälschung, Würzburg, Ergon.

Bucknill, John Alexander Strachey; Utidjian, Haig Apisoghom (1913). The Imperial Ottoman Penal Code: A Translation from the Turkish Text, with Latest Additions and Amendments Together with Annotations and Explanatory Commentaries upon the Text and Containing an Appendix Dealing with the Special Amendments in Force in Cyprus and the Judicial Decisions of the Cyprus Courts, London, Humphrey Milford-Oxford University Press.

Cerquiglini, Bernard (1989). Éloge de la variante. Histoire critique de la philologie, Paris, Le Seuil.

Chaker, Salem, ed. (1998). Langues et pouvoirs. De l'Afrique du Nord à l'Extrême-Orient, Aix-enProvence, Édisud.

Culang, Jeffrey (2017). Liberal Translations: Secular Concepts, Law, and Religion in Colonial Egypt, unpublished PhD dissertation, New York, City University of New York.

Didi-Huberman, Georges (2008). La Ressemblance par contact. Archéologie, anachronisme et modernité de l'empreinte, Paris, Éditions de Minuit.

Dubreuil, Laurent (2008). L'Empire du langage, Paris, Hermann.

Duval, Frédéric (2007). ‘À quoi sert encore la philologie ? Politique et philologie aujourd'hui,' Laboratoire italien, 7: Del Vento, Christian; Fournel, Jean-Louis eds., Philologie et politique, pp. 17-40. DOI: 10.4000/laboratoireitalien.128

Eisenstein, Elizabeth L. (2002). 'An Unacknowledged Revolution Revisited,' American Historical Review 107(1), pp. 87-105. DOI : 10.1086/ahr/107.1.87

Eisenstein, Elizabeth L. (1979). The Printing Press as an Agent of Change: Communications and Cultural Transformations in Early-modern [sic] Europe, Cambridge, Cambridge University Press (2 vols.).

Eldem, Edhem (2011). 'Chaos and Half Measures: The Ottoman Monetary "System" of the Nineteenth Century,' in Eldem, Edhem; Petmezas, Socrates eds., The Economic Development of South-Eastern Europe (1830-1914), Athens, Alpha Bank, pp. 251-305.

Escudier, Alexandre (2009). ' “Temporalisation” et modernité politique : penser avec Koselleck, Annales. Histoire, Sciences Sociales 64(6), pp. 1269-1301. URL: www.cairn.info/revue-annales-2009-6page-1269.htm

Genette, Gérard (1972). Figures III, Paris, Le Seuil.

Goodman, Nelson (1968). Languages of Art: An Approach to a Theory of Symbols, New York, BobbsMerrill.

Grafton, Anthony (1990a). Forgers and Critics: Creativity and Duplicity in Western Scholarship, Princeton NJ, Princeton University Press.

Grafton, Anthony (1990b). 'Notes from Underground on Cultural Transmission,' in Grafton, Anthony; Blair, Ann eds., The Transmission of Culture in Early Modern Europe, Philadelphia, University of Pennsylvania Press, pp. 1-7.

Heyd, Uriel (1954). Language Reform in Modern Turkey, Jerusalem, Israel Oriental Society. 
Judet de la Combe, Pierre (2008). ‘Sur les conflits en philologie,' Texto !, 13(1-2). URL: www.revuetexto.net/index.php?id=106

Judet de la Combe, Pierre; Wismann, Heinz (2004). L'Avenir des langues. Repenser les humanités, Paris, Éditions du Cerf.

Katiboğlu, Monica Marie (2017). Haunted Modernities: Linguistic and Cultural Change in Ottoman Turkey, unpublished PhD dissertation. Irvine CA, University of California.

Kohlberg, Etan; Amir-Moezzi, Mohammad Ali, ed. (2009). Revelation and Falsification: The Kitāb alqirā'āt of Ahmad b. Muhammad al-Sayyārī, Leiden Boston, Brill.

Koselleck, Reinhart (2011 [1972]). 'Introduction and Prefaces to the Geschichtliche Grundbegriffe,' (Richter, Michaela transl.), Contributions to the History of Concepts 6(1), pp. 1-5, 7-25, 27-37. DOI : $10.3167 /$ choc.2011.060102

Koselleck, Reinhart (1982). 'Begriffsgeschichte and Social History' (Tribe, Keith transl.), Economy and Society 11(4), pp. 409-427. DOI: 10.1080/03085148200000015

Landau, Jacob M. (2008). 'Attempts at Romanization in the Middle East and Central Asia,' in Sadgrove, Philip ed., Printing and Publishing in the Middle East: Papers from the Second Symposium on the History of Printing and Publishing in the Languages and Countries of the Middle East, Bibliothèque nationale de France, Paris, 2-4 November 2005, Oxford: Oxford University Press on behalf of the University of Manchester. [Journal of Semitic Studies Supplement 24], pp. 185-192 (with plates on pp. 314-323).

Landau, Jacob M. (1990). 'Language Policy and Political Development in Israel and Turkey,' in Weinstein, Brian ed., Language Policy and Political Development, Norwood NJ, Ablex Publishing Corporation, pp. 133-149.

Launay, Marc de (2016). 'Philologie et esprit historien,' Les Cahiers philosophiques de Strasbourg 40: Nietzsche philologue et philosophe, pp. 37-53. DOI : 10.4000/cps.430

Messick, Brinkley M. (1993). The Calligraphic State: Textual Domination and History in a Muslim Society. Berkeley Los Angeles Oxford, University of California Press.

Moatti, Claudia (2011). 'Historicité et altéronomie : un autre regard sur l'histoire,' Politica antica 1, pp. 107-118.

Narayana Rao, Vlecheru; Shulman, David; Subrahmanyam, Sanjay (2001). Textures of Time: Writing History in South India 1600-1800, Delhi, Permanent Black.

Özmen, Ceyda (2016). 'Translating Science in the Ottoman Empire: Translator-Educators as “Agents of Change" in the Ottoman Scientific Repertoires (1789-1839),' Osmanlı Araştırmaları / The Journal of Ottoman StudiesXLVIII, p. 143-170.

Paker, Saliha (2006). 'Ottoman Conceptions of Translation and its Practice: The 1897 "Classics Debate" as a Focus for Examining Change,' in Hermans, Theo ed., Translating Others II, Manchester, St. Jerome, pp. 325-348.

Perry, John R. (1985). 'Language Reform in Turkey and Iran,' International Journal of Middle East Studies 17(3), pp. 295-311. URL: www.jstor.org/stable/163501

Petrucci, Armando (1993). Public Lettering: Script, Power and Culture (Lappin, Linda transl.; orig. ed. 1980), Chicago, University of Chicago Press.

Radnóti, Sándor (1999). The Fake: Forgery and Its Place in Art (Dunai, Ervin transl.), Oxford, Rowman \& Littlefield. 
Redhouse, James W. (1890). A Turkish and English Lexikon, Istanbul, Boyajian.

Reig, Daniel (1971). ‘Antonymie des semblables et corrélation des opposés en arabe,' Bulletin d'études orientales 24, pp. 135-155. URL: www.jstor.org/stable/41603317

Reimitz, Helmut (2014). 'From Cultures to Cultural Practices and Back Again,' in Rodgers, Daniel T.; Raman, Bhavani; Reimitz, Helmut eds., Cultures in Motion, Princeton, NJ Oxford, Princeton University Press, pp. 270-278.

Reinkowski, Maurus (2005). Die Dinge der Ordnung. Eine vergleichende Untersuchung über die osmanische Reformpolitik im 19. Jahrhundert, Münich, Oldenbourg.

Sabev, Orlin (2018). Waiting for Müteferrika: Glimpses on Ottoman Print Culture, Boston, Academic Studies Press.

Sabev, Orlin (2006). Müteferrika ya da İlk Osmanl Matbaa Serüveni (1726-1746): Yeniden Değerlendirme, Istanbul, Yeditepe Yayınevi.

Strauss, Leo (1952). Persecution and the Art of Writing, Glencoe IL, The Free Press.

Strauss, Johann (2002), 'Müdafaa'ya mukabele et mukabeleye müdafaa : une controverse islamochrétienne dans la presse d'Istanbul (1883),' in Herzog, Christoph; Motika, Raoul; Ursinus, Michael eds., Querelles privées et contestations publiques. Le rôle de la presse dans la formation de l'opinion publique au Proche Orient, Istanbul, Isis, pp. 55-98.

Suleiman, Yasir (2003). The Arabic Language and National Identity: A Study in Ideology, Edinburg, Edinburgh University Press.

Suleiman, Yasir (1999). Language and Society in the Middle East and North Africa: Studies in Variation and Identity, London New York, Routledge.

Szurek, Emmanuel (2013). Gouverner par les mots. Une histoire linguistique de la Turquie kémaliste, unpublished doctoral dissertation, Paris, École des Hautes Études en Sciences Sociales.

Şiviloğlu, Murat R. (2018). The Emergence of Public Opinion: State and Society in the Late Ottoman Empire, Cambridge New York, Cambridge University Press.

Tachau, Frank (1964). 'Language and Politics: Turkish Language Reform,' The Review of Politics 26(2), pp. 191-204.

Toenies Keating, Sandra (2014), 'Revisiting the Charge of Tahrif: The Question of Supersessionism in Early Islam and the Qur'an,' in Levy, Ian Christopher ; George-Tvrtković, Rita ; Duclow, Donald F. eds., Nicholas of Cusa and Islam: Polemic and Dialogue in the Late Middle Ages, Leiden, Brill), pp. 202-217. DOI: 10.1163/9789004274761_014

Topal, Alp Eren (2017a). ‘Against Influence: Ziya Gökalp in Context and Tradition,' Journal of Islamic Studies 28(3), pp. 283-310. DOI: 10.1093/jis/etw059

Topal, Alp Eren (2017b). From Decline to Progress: Ottoman Concepts of Reform 1600-1878, unpublished PhD dissertation, Ankara, İhsan Doğramacı Bilkent University.

Wigen, Einar (2018). State of Translation: Turkey in Interlingual Relations, Ann Arbor MI, University of Michigan Press. DOI: 10.3998/mpub.9910072 


\section{NOTES}

1. What the Ottomans generically referred to since the mid-nineteenth century as 'monetary documents' (evrâk-ı nakdiyye) included any type of bill that could be negotiated or transmitted as part of a financial transaction. We shall thus talk simply of notes. Cf. Eldem 2011.

2. This definition of expertise is Bessy, Chateauraynaud's (2013: 301, translated from the French): 'un espace de calcul dans lequel figurent en bonne place des intentions.'

3. Ibid. (translated from the French): 'nous ne savons pas - comme les acteurs - ce qui est déposé intentionnellement dans les objets et ce qui est le produit de corps à corps, de plis, de relations matérielles non intentionnelles (usures, traces de contacts ou de chocs, rapports de force entre des substances, états et phénomènes intempestifs, etc.).'

4. None better than scholars dealing with art forgery, like Nelson Goodman (1968) and Sándor Radnóti (1999), highlighted this precariousness. See in particular Radnóti 1999: 116, 207.

5. Let us quote from two instances:

- BOA, I.DH. 243/14825, doc. 2, memorandum to the Palace, 27 Muharrem 1268 [November 22, 1851]: 'given their excessive circulation, the documents in question [bearer vouchers for twenty pounds without interest] will rapidly become worn; that is why it has been decided to entirely renew them at the end of the year' (evrâk-ı mezkûre ziyâde tedâvül edecegi cihetle az vakitde fersûde olacaġından senesi Hitâmında cümleten tecdîdi șûreti karâr-gîr olmuş).

- BOA, İ.MMS. 132/5677, draft of a 'notice,' 30 Ramażân 1277 [April 11, 1861]: 'the notes in circulation are ageing and becoming worn, hence the need to exchange them in their entirety in December' (tedâvülde bulunacak kavâ’imiñ eskiyüb fersûde olması cihetle aralı̣da 'umûmen tebdîli lâzım).

6. Escudier 2009: 1271 (translated from the French): 'faire apparaitre, en les distinguant et en les articulant ensemble, les différents niveaux d'analyse mis en œuvre par l'entreprise même de l'histoire des langages politiques modernes.'

7. Judet de la Combe, Wismann 2004: 80, translated from the French: 'Au-delà des mots, l'effort de formalisation porte nécessairement aussi sur les relations que les termes ainsi définis peuvent entretenir. Ces deux opérations sont indissociables : les termes scientifiques ne désignent pas des entités isolées, mais, puisqu'il s'agit de terminologies visant à la cohérence, ils sont signes des relations entre ces entités.'

8. Compare Berman 2008: 51 (translated from the French, emphasis in the original): 'À ce tissu de base du texte, peu défini, s'oppose un réseau conceptuel plus rigoureux qui lui est, pour ainsi dire, enchâssé. La traduction se doit de respecter le mode d'insertion de ce réseau dans le tissu du texte.'

9. Moatti 2011: 111 (translated from the French, emphasis in the original): ‘[l]a capacité d'une société à l'imagination politique (à l'altérité comme à l'altération), ce que j'appelle donc l'altéronomie.'

10. For another telling example of this editing practice, see Aymes 2008.

11. See $E I^{2}$, vol. 10 (2000), s.v. "Tahrif " (Hava Lazarus-Yafeh). As a widespread motif of polemic writings by Muslim authors accusing Jews and Christians of having deliberately tampered with their own respective Scriptures, the notion has been of great importance to Islamic studies at large (see Brunner 2001; Kohlberg, Amir-Moezzi 2009; Toenies Keating 2014). Fewer studies deal with tahrif in an Ottoman context, and they tend to give precedence (as does the present text) to the primary meaning of the term-namely, that of changes or alterations of words whatever their textual setting (Strauss 2002; Aydın, Keskin 2008; Aymes 2019).

12. The word interpreted here as 'silinti' is barely legible in the original document, which is why I chose to leave it in square brackets. 
13. BOA, C.DH. 55/2701, unsigned, undated report, receipt registered on 16 Șafer 1210 [September 1, 1795]: "ekserer tîmâr ü zeâmetleriñ berevâtını alub mutașarrıflarınıñ isimlerini hakk ve dil[e]digi ismi yazub".

14. BOA, İ.DH. 711/49736, doc. 1, report from the Council of the Ministry of War, 4 Ramażân 1292 [October 4,1875]: “Beyrût ḳomândânlıġına yazılmış bir tahrîrâtıñ elkâabıyla hââi oldığı neferiñ ismini hakk ve elkâab ve zarf üzerini merkez komândânlığına olaraḳ tahvîl ve neferiñ ismini digerine tebdîl eyledigi".

15. A 'dialectical image' may be defined as one 'where the past and the present have gone astray, transformed and criticized one another, so as to form what [Walter] Benjamin called a constellation, a dialectical configuration of heterogenous times,' dixit Georges Didi-Huberman (2008: 13; translated from the French: 'image dans laquelle passé et présent se dévoient, se transforment, se critiquent mutuellement pour former quelque chose que Benjamin nommait une constellation, une configuration dialectique de temps hétérogènes'). Cf. Benjamin 1999: 475.

16. BOA, İ.MVL. 44/811, doc. 4 , copy of a report by the High Council of Judicial Ordinances, undated ( late receb 1258 /early September 1842): "bu makûle țaraf-1 salțanat-1 seniyyeden verilen evâmir-i 'aliyye ve me'mûrîn-i devlet-i 'aliyye cânibinden i'țâ olunan evrâk-1 resmiyye ve sâ'ireye taḳlîd eden ve ba'żı maḥallerini ḥakk ü tag̉yîr eyleyen sâHુtekâr şaḤıṣ isbât olunduḳdanșoñra te'dîben cünḥasınıñ derece-i cesâmetine göre beş seneden on seneye ḳadar vaż ${ }^{\star}-1$ kürek olunması kânûn-nâme-i hümâyûn aḥkâm-ı münîfesi iḳtiżâsından bulunmus".

17. 1858 Ottoman Penal Code, article 152 (taken from Akgündüz 1986: 859): "Memurînden her kim olur ise olsun, hîn-i icrâ-yı me'mûriyetinde muḳaddemâ yapılmış olan i'lâm ve mażbața ve sâ'ir senedâtın veyâ defter ve cerîde ve sâ'ir sicillâtın, gerek șutûrı arasına 'ilâve ve yâHûd Huațt ve Hatem veyâ imżâyı taġyîr ile veyâ bir şaH̦șın ismi yerine diger bir şaHș̣ın ismini ḳoymakla sâţtekârlık eder ise, on seneden aşağı olmamak üzere muvaḳkaten kürek yâtûud ḳal'e-bendlik cezâsıyla mücâzât olunur. Ve eger bu sâHुtekârlığı eden kimse me'mûrînden degil ise, yedi seneyi tecâvüz etmemek üzere muvaḳkat kürek yâHûd kal'e-bendlik cezâsıyla mücâzât ḳılınır." English translation adapted from Bucknill, Utidjian 1913: 112.

18. BOA, İ.MVL. 365/15970, doc. 15, round robin from the High Council of Judicial Ordinances, 9 Cemâzîü'l-evvel 1273 [January 5, 1857]: "țarîki ref' ü hakk olunarak".

19. Compare Türkiye Diyanet Vakfi İslam Ansiklopedisi, 13 (1996), s.v. “Gedik”(Ahmet Akgündüz). URL: https://islamansiklopedisi.org.tr/gedik

20. The even more erroneous dating in the first recorded deed ("9 Z [December 4, 1878] and March 11 of the year 84 [March 23, 1868] [sic]") prompts no further explicit comment from the investigators, yet they take particular care to state that these dates were "placed" (mevíû́ $)$ underneath the text. Reproducing the discrepancy without commenting on it may here be understood as an ironic indication of their suspicion of forgery. 'If a master of the art of writing commits such blunders as would shame an intelligent high school boy, it is reasonable to assume that they are intentional, especially if the author discusses, however incidentally, the possibility of intentional blunders in writing.' (Strauss 1952: 30)

21. Except for the noted correction, the report's initial and final drafts are identical. 


\section{ABSTRACTS}

The study of language change is a necessary correlate of historical semantics, if not a precondition for it. Yet there are many ways of looking for linguistic alterations: they could be operating at the level of 'discourse,' i.e. within an arborescence of ideas; or, they could derive from the material layout of linguistic artefacts. This paper leans toward the latter stance: it commits to analysing language change literally, at its most material, as a physical process of alteration. In administrative and judicial sources from the nineteenth- and early-twentiethcentury Ottoman Empire, that process was referred to (among other names) as tahrîf. Focusing on the materiality of such rewritings, interpolations, and emulations, means combining two kinds of historical semantics: one that rests on discrete and meaningful lexemes, the other on conceptual relationships embedded in phrasings that determine the choice of words. The case for methodological materialism also implies that language change be understood not primarily as a macroscopic, long-running, institutional process, but as a minute, largely ephemeral, practical event. This way of dealing with historical documents as intrinsically precarious readings lays the groundwork for approaching language change from below.

\section{INDEX}

Keywords: forgery, Ottoman Empire, methodological materialism, philology, justice, taḥrîf

\section{AUTHOR}

\section{MARC AYMES}

Centre National de la Recherche Scientifique / École des Hautes Études en Sciences Sociales (Paris)

Centre d'Études Turques, Ottomanes, Balkaniques et Centrasiatiques, CETOBaC, UMR 8032 marc.aymes@ehess.fr 